\title{
A importância cultural das águas no Amazonas
}

\author{
Leno José Barata Souza'
}

\section{$\mathrm{Na}$ "Região de Manaus"}

Entre os 14 dos nossos entrevistados, 09 são interioranos, ou seja, chegaram a Manaus vindo especialmente de regiôes limítrofes à capital amazonense. ${ }^{2}$ Esse fator, em um primeiro momento, causou certa apreensáo e, em seguida, algumas inquietaçóes, como: que interiores eram esses? Quais as suas relaçóes com a cidade de Manaus?

Mario dos Santos, João Cesário da Silva, Vivaldo Correa Lima e Sebastião Garcia, por exemplo, vieram de Manaquiri, uma ilha cercada pelo Paraná do Barroso, Lago Manaquiri e o Rio Solimões, esse último, o caminho mais curto para chegar a Manaus.

Essa ilha, paraná e lagos pertenciam ao distrito do Careiro, um conjunto de ilhas maiores banhadas pelo Rio Solimóes/Amazonas e paranás do Cambixe e Careiro, destacando-se em seu interior o grande Lago dos Reis.

1 Doutor em História pela Pontifícia Universidade Católica de São Paulo. O artigo é parte da tese “Cidade Flutuante: uma Manaus sobre as águas (1920-1967)”, sob orientação da Prof.a Dra Yara A. Khoury com Bolsa CNPQ e CAPES (PDE-Universitá di Roma "La Sapienza”). E-mail: lenojbarata@ ig.com.br.

2 Para evitar uma série de repetiçôes, sublinho que todas as entrevistas foram feitas pelo autor, em Manaus, entre os anos de 2005 e 2009. No final do artigo arrolei mais detalhadamente os entrevistados. 
Ali próximo ainda, em outro lago, o do Janauacá, nasceu outra entrevistada, a Senhora Maria do Nascimento Borél.

O circuito fluvial é bastante conhecido por esses ribeirinhos que, a remo, ou em dias de melhor sorte, a reboque em barco a motor, subiam pelo Rio Solimôes contornando todo esse rendilhado líquido até a desembocadura com o Rio Negro, dali já se podia entrever, do outro lado, a cidade de Manaus, vencendo uma desafiante travessia de $60 \mathrm{~km}$.

Na margem de Manaus, agora subindo pelo Rio Negro, chega-se ao distrito de Airão, situado na foz do Rio Jaú, tributário secundário do Negro, no qual nasceu outra de nossas narradoras, a Senhora Creuza Rodrigues de Andrade. No tempo dessas vidas, Airão, as ilhas do Careiro e Manaquiri, Janauacá, lagos e paranás, administrativamente formavam uma única unidade política pertencente a Manaus, ou seja, a atual capital amazonense projetava-se tanto de um lado quanto de outro do Rio Solimóes/Amazonas.

Mapear a origem dos entrevistados ajudou-me tanto a delinear antigos limites de uma Manaus bastante diferente das dimensóes territoriais da atual cidade com seus $11.408 \mathrm{~km}^{2}$, como a refletir sobre como essas fronteiras naturais eram experimentadas e cotidianamente resignificadas pelos modos de vida dos caboclos ribeirinhos.

Em 1925, Bittencourt (1985, p. 14 e 171) apontou para a capital uma área de $47.874 \mathrm{~km}^{2}$, dividida em 11 sedes distritais, mais de quatro vezes os limites atuais; diferença que se torna maior se recuperarmos as dimensóes de 1938, quando são criados em Manaus mais dois distritos: o $10^{\circ}$ distrito do Careiro, formado pelas ilhas do Careiro e Manaquiri, e o $1^{\circ}$ distrito do Airão no Rio Jaú, dando formas a uma cidade de $84.569 \mathrm{~km}^{2}$, (INTERVENTORIA FEDERAL, 1942, p.13) ${ }^{3}$, quase oito vezes o território atual, assumindo contornos de uma grande regiáo na qual Manaus era, como ainda é, o centro.

Em 1956, Lúcio de Castro Soares cartografou a antiga "Região de Manaus". Objetivando oferecer uma ideia dos domínios políticos dessa "grande Manaus" de outrora, reproduzimos, a seguir, o Mapa I de Soares potencializando os caminhos e lugares que, sobretudo por intermédio das narrativas orais, começaremos a percorrer:

3 Em 1955, Careiro e Airão passam à condição de municípios autônomos. As separaçóes, todavia, continuaram de difícil assimilação para os moradores do lugar, acostumados com as relaçôes sociais, culturais, econômicas e político/administrativas que os ligavam a Manaus. 


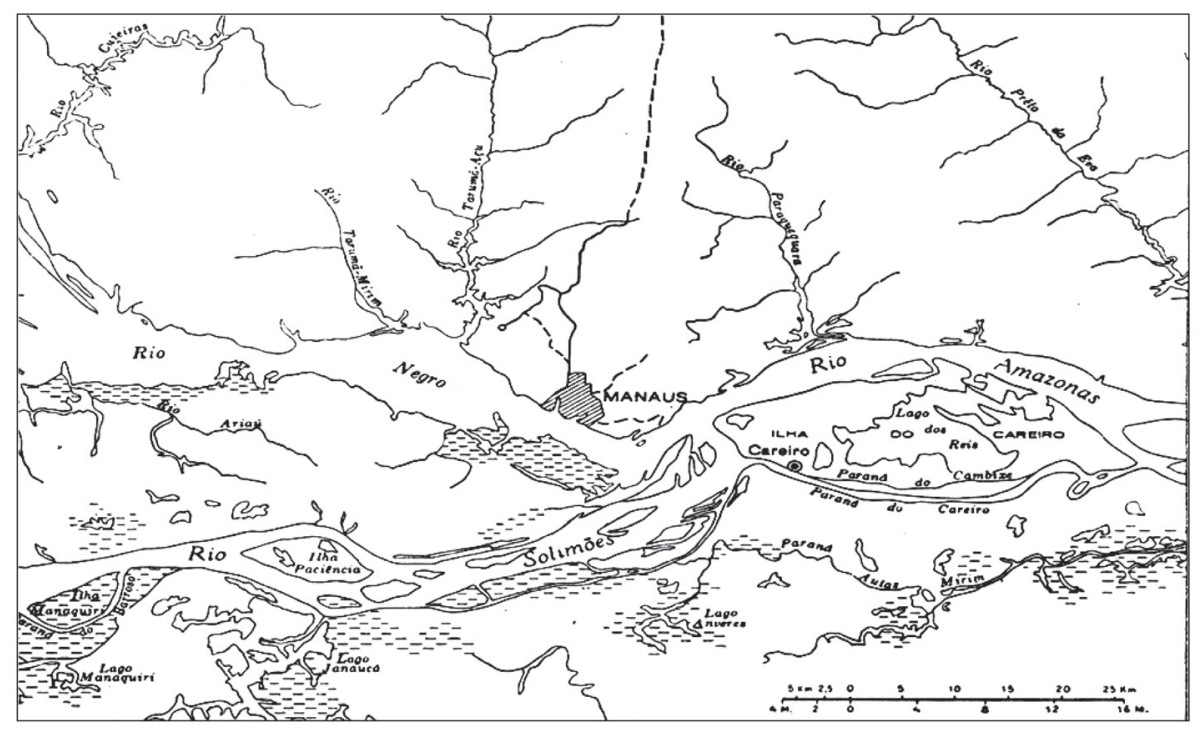

MAPA I: Antiga Região de Manaus

Fonte: SOARES, Lúcio de Castro. "Amazônia", p. 223.

Interessa-nos, todavia, transbordar as linhas do mapa, riscar outras, carregá-las de vidas, vivências e sobrevivências entrecruzadas, lugares de disputas e, por isso, politizados; territórios de experiências e, portanto, lugares de memórias também.

Para os urbanistas, "o espaço do mapa é um espaço; o espaço real vivido é o território", prenhe de valores e significados próprios, vivificando uma poderosa assinatura cultural em cujas linhas se flagra uma "cartografia das relaçôes sociais” (Rolnik, 2001, p. 142) que vai além dos ambientes naturais e marcos político/administrativos, entendendo-os ainda como paisagens sociais, expressóes culturais, lugares de histórias e memórias cujas narrativas orais propóem novos limites e projetam outras imagens.

Rios, lagos, paranás e ilhas representam para os moradores locais, como os entrevistados com quem dialogo, um significativo modo de viver que influencia suas vidas, fortemente atuante em suas mais variadas sociabilidades: nascimento, lazer, trabalho, moradia, projetando sonhos, norteando suas crenças, marcando suas lembranças. Assim, os lugares narrados são menos descritos e mais reconstruídos. 


\section{Na região das águas}

Em uma das conversas com Vivaldo Correa, pedi para que me contasse sobre o interior onde morava, e obtive uma narrativa que, ao mesmo tempo, ilumina alguns traços do Mapa I, mas traça novamente outros, estica caminhos e, especialmente, atiça a imaginação:

... O Manaquiri, ele é um Paraná, né, só que ele é longo, né, é bem distante, mas tem outros, outros [paranás], outras comunidades lá pra dentro do, do, do Manaquiri, né, ele, ele num vai só até onde eu morava não, ele pega e vai..., por sinal ele, ele entra aqui em baixo, ele entra aqui em baixo e vai arrodeando, ele vai passar, ele vem passar por trás do Janaucá, faz àquela volta, né, eu nasci lá. (Entrevista com Vivaldo Correa Lima, Manaus, Janeiro de 2006).

A narrativa de Vivaldo começa com uma surpreendente definiçáo geográfica, "é um paraná", grande, indo além da sua casa, "arrodeando" pela outra margem do Lago Manaquiri, contornando o Lago de Janauacá, chegando a outras comunidades isoladas, "lá pra dentro", onde o menino Vivaldo, "na poupa da canoa", costumava ir, com seu pai e irmãos mais velhos pescar o almoço e o jantar de toda a família.

Distante, "bem distante", menos pelos $60 \mathrm{~km}$ que separam o Manaquiri de Manaus, uma distância irrisória frente aos limites colossais da Amazônia, e mais pelo lento e sofrido compasso das remadas que traziam a família de Vivaldo num bateláo alugado, carregado de carvão para ser vendido em Manaus que, como me contou, junto com a "... lenha mocotó, aqueles pedaço de lenha cortado num só tamanho, né, era pra queimar no fogo...” garantiam a iluminação e o fogão de várias casas na capital.

A embarcação, apinhada de carvão, coberta com uma lona escura, ziguezagueando nas águas do rio, segundo Vivaldo, parecia “... um monstro de batelão", grande, pesado e arisco sobre as traiçoeiras águas do Solimóes, aumentando os esforços da família, um penar que Vivaldo, ainda em tenra idade no fim dos anos trinta, apenas podia assistir e guardar na memória.

O "monstro" de sua narrativa não o assustava, pelo contrário, fascinava-o, encarnando, aos olhos do menino, um dos muitos seres fantásticos do imaginário ribeirinho amazônico, milenarmente ligado à água, resignificado 
nas mentes por geraçóes e gerações de narrativas, repletas de aventuras, surpresas e fascínios, sensaçóes que Vivaldo, desde os quatro anos, experimentava nas constantes viagens com sua família, subindo e descendo as correntezas do rio em direção à capital.

As narrativas de Vivaldo recontam modos de vida de uma realidade cultural peculiar, apreendida à luz das experiências de quem, como ele, "nasceu lá”, nos barrancos vizinhos, as águas significando memórias e reconstruindo lugares.

Conheci Vivaldo em janeiro de 2006, por intermédio de uma ex-aluna que o "recomendou" devido à prodigiosa memória dos seus 73 anos de vida, o que fui comprovando ao longo dos nossos encontros. Ele gosta de conversar sobre tudo, mesmo sobre coisas que pouco conhecimento possui. $\mathrm{O}$ assunto nem sempre é o mais importante, narrar, contar algo sobre a sua e outras vidas é o que lhe dá prazer, o faz sentir-se importante, personagem atuante e sujeito social das histórias que me conta.

Em nosso último encontro Vivaldo estava todo feliz, finalmente o divórcio havia saído (ele é separado de Dona Raimunda), estava de namorada nova e vivia ocupado com os afazeres do centro de convivência de idosos do bairro. Sendo do coral, também estava empolgado com a perspectiva de conseguir cantar no imponente e elitista Teatro Amazonas, quase um sonho para o ex-morador do Manaquiri, vendedor de carvão, "bolacheiro" (vendedor de páes pela cidade), extrator de pau rosa e soldado da Polícia Militar aposentado.

"E vai arrodeando (...) faz aquela volta, né". Em uma das "curvas" da memória de Vivaldo Correa, cheguei ao Lago de Janauacá (Mapa I), e ali conheci Maria do Nascimento que, numa família de dez irmãos, no lago nasceu em 1918. Maria, depois de eu lhe perguntar se era amazonense, contou-me na pequena varanda de sua atual casa: “... naquela época, Manaus era nova ainda, nós morava [em Janauacá]”.

As narrativas de Maria do Nascimento também foram ressignificando as formas propostas por Lúcio de Castro Soares para a "Região de Manaus", interligando lugares, misturando-os, refazendo limites, recriando identidades.

Maria do Nascimento, mais do que me dizer se era ou não amazonense, justificou de imediato a sua resposta: "é, porque, nessa época nós morava em Janauacá; nasci em Manaus também, em 10 de Junho, nós morava em Janauacá, foi lá que nós nascemos”. As narrativas de Maria justapóem, em um 
primeiro momento, o Lago de Janauacá e a cidade de Manaus, colocando-os como um mesmo berço de nascimento, "nasci em Manaus também”, concluiu a narradora.

Em seguida, porém, é o lago que ganha força em sua narrativa, "foi lá [no Lago de Janauacá] que nós nascemos”; é o lago que contagia as narrativas de Maria, são as águas, em última instância, que definem os locais de origem para a maioria da população ribeirinha: o lago para Maria Borél, o paraná para Vivaldo Correa.

Baseado no que observei no Mapa I e nos meus conhecimentos básicos de geografia, defini o Manaquiri como uma ilha: pedaço de terra cercado de água por todos os lados. Vivaldo, por sua vez, foi taxativo: “... o Manaquiri, ele é um paraná...”, ou seja: braço de rio, canal que liga dois rios. O centro de minha definição é a terra, o de Vivaldo é a água.

Se eu busquei conceitos no senso comum, nas explicaçóes de uma geografia básica e na observação fria das linhas dos mapas, Vivaldo, por outro lado, os apreendeu partindo das próprias experiências de quem "nasceu lá" em uma casa de madeira, cujo terreno findava as margens do Lago Manaquiri. Ali seus pais cultivavam mandioca (aipim), com a qual faziam farinha para sustentar os outros sete irmãos de Vivaldo.

Em outros lagos e paranás, Vivaldo ia pescar com seu pai, “... meu pai, a vida dele era pescar..."; ali, sua família também fazia a "caera” (forno artesanal, um buraco na terra em que colocam madeiras para serem queimadas) para produzir o carvão vegetal. Dali também partiam para Manaus a fim de vender a produção.

Quando pedi para outro entrevistado, o Senhor Francisco Pereira da Silva, que contasse sobre a sua vida em Coari (Alto Solimôes) ele, ao contrário dos outros narradores, lembrou-se muito bem do município em que nasceu: nome, localização e limites. Em seguida, mais uma vez, na imagem narrada por Francisco, gradativamente vão sobressaindo os caminhos das águas que há geraçôes estão presentes na vida e nas experiências de sua família:

Não, é o seguinte, eu nasci no Quebra, município de Coari em Ipixuna, entre Ipixuna e São Raimundo, chamamos de Quebra; é um município, tem uma ilha na frente e um curso de água, assim um rio que passava por trás da praia, nós nascemo lá, nasci lá no Quebra, município de Coari; então chamado. Lá nós temos, nós tinha um lago que chamava Jubará, 
ainda existe este lago ainda lá, agora parece que é preservado pela, pela é... O governo IBAMA, então lá nós, nós si criemo lá, mamãe ela, meus parente é lá, meu pai também, meu avô, tudinho era de lá.(Entrevista com Francisco Pereira da Silva, Manaus, Janeiro de 2008).

Nas regiôes interioranas, em seus barrancos, ribeiras, embocaduras, calhas, várzeas, paranás e furos, o multiforme rendilhado fluvial amazônico, além de nortear o rumo das vidas, marca os locais de origem, atuando como uma referência que identifica e localiza os sujeitos em meio a uma peculiar paisagem social.

Excetuando as metrópoles regionais Belém e Manaus, na Amazônia é o rio, o paraná, a boca, o lago que contém as cidades, municípios, vilas, distritos, e não o contrário. Mais do que sobrepujá-las por suas dimensóes, esses circuitos fluviais se sobrepóem como uma expressão cultural mediadora das mais variadas sociabilidades, artérias prenhes de vidas que encarnam as histórias e memórias dos moradores que dão movimento ao rio e são por ele conduzidos.

Em 1932, o general Frederico Rondon, representante dos interesses brasileiros em questóes de fronteiras com a Colômbia, passou pela regiáo do Rio Negro e também não deixou de notar as fronteiras líquidas, móveis, próprias das várzeas amazônicas, levadas e resignificadas ao sabor das necessidades das vidas dos que por ali transitam, trabalham e moram merecendo as seguintes anotaçóes em seu "diário de bordo": "As fronteiras das naçóes ribeirinhas surgem assim à beira-rio, escorando-se nos marcos naturais dos acidentes, de foz em foz, oscilando a leste e a oeste, ao sul e ao norte" (Rondon, 1969, p. 142).

Se as referências identitárias de um grupo social, como apregoa Arantes (2000, p. 132-144), vinculam-se a um sentimento de saber lidar com o meio natural que o localiza em um complexo mapa social, um dos "endereços" mais emblemáticos e poderosos que nos leva aos caboclos amazônicos é o rio, o igarapé, o furo, o paraná, a várzea, o alagado.

Sua cultura é profundamente marcada pela relação com as águas; sobre elas podem construir suas casas, delas tiram parte dos alimentos, nelas organizam seus meios de transporte e comunicação, trabalhos, lazeres e outras sociabilidades. Essas águas habitam e significam as histórias contadas, as lendas, os mitos, atravessam suas festas e rituais, sendo parte de um imagiuo nário significativo para suas vidas e sua realidade. 
As trajetórias de Creuza de Andrade, nestes termos, também riscam outras linhas nessas fronteiras aquáticas que "andam" e transformam a paisagem social do lugar. Ela me contou que nasceu no Rio Jaú, aos sete anos, e junto com a família, veio pela primeira vez a Manaus e até os nove anos, "nós tivemo no Rio Negro, lá no Pagodáo", um ramal de águas próximo à praia do Tupé no Rio Negro, a duas horas de barco de Manaus.

Em seguida, sua irmã mais velha conheceu um rapaz no dito Pagodão com quem se casou em Manaus, vindo a família toda para a celebração na capital de onde "... nós fomo pro... baixamo na Vila de Pedra em paraná do Ramos...", sede do município de Barreirinha, Baixo Amazonas, a 420 km por via fluvial da capital, próximo a Parintins. Quando perdeu sua máe, aos quatorze anos, foi trabalhar como empregada doméstica em Barreirinha na casa de uns professores; anos depois, estes se mudaram para Manaus, convencendo a jovem Creuza a vir para a capital, onde foi trabalhar na casa da irmã de seu antigo patrão de Barreirinha.

Depois de sérios desentendimentos com sua patroa em Manaus, Creuza, já com 19 anos, retorna para o interior indo morar com sua tia nas terras baixas do Paraná do Curari que, segundo Bittencourt (1985, p. 88), fica “...pouco acima da entrada do Careiro...”, especificamente em um paraná secundário chamado Curarizinho, afluente do grande Paraná do Mamori. Pouco tempo passou ali, retornando em seguida para Manaus para morar na casa de parentes à beira do Igarapé da Cachoeirinha.

À certa altura da conversa com Francisco Pereira da Silva, pude dimensionar melhor o quão complexa é a compreensão dessas fronteiras líquidas, mesmo para pessoas como eu, originário e morador da região, mas que ainda sentia sérias dificuldades quando o diálogo chegava a esse ponto.

$\mathrm{Na}$ segunda entrevista, depois de lhe pedir maiores explicaçóes sobre sua vida no interior, comentei: "o senhor na primeira entrevista falou da cidade de Copéa”. Em seguida reproduzo o diálogo que se seguiu oferecendo uma ideia dos desconcertos pelos quais passava, das tentativas de entendimento e da paciência de Francisco da Silva:

FS-... Tinha um tio que nós nunca tinha conhecido, aí ele, nesse dia, ele apareceu, deu um recado pra mamãe e nós fumo lá na casa dele, aí ele morava no Copéa; 
LS- Copéa é o que?

FS- É um rio, é um rio grande que pega daí do Coari, acima de Coari, daí [inaudível] da fronteira é... Tabatinga, então aí ele morava lá, e onde ele morava tinha um município que chamava de Porco Magro.

LS- Ah! Porco Magro é em Copéa?

FS- Em Copéa.

LS- Ah, tá certo.

FS- E o Copéa e o meu tio, ele ficou lá, mamãe viajou aqui pro Solimões, ele ficou no Copéa. (Entrevista com Francisco Pereira da Silva, Manaus, Setembro de 2008).

A questão encontra-se mais no meu comentário do que na resposta de Francisco da Silva. Ao não entender o que era o Copéa, acreditei de imediato, em nosso segundo encontro, tratar-se de uma pequena cidade, um distrito, uma vila, ou outro lugarejo marginal da hinterlândia amazônica, espaços que, para mim, deveriam referenciar os lugares de origem e moradia, mas, como me explicou Francisco, dizia respeito a um grande rio que vai até a cidade de Tabatinga, porta fronteiriça com a Colômbia.

Para Francisco, morar no Rio Copéa, como seu tio morava, era algo internalizado e corriqueiro em sua vida de ribeirinho, de morador do Quebra no município de Coari, onde, segundo suas narrativas, tinha um curso d'água que levava a uma ilha na frente, um rio que passava atrás da praia e ainda o famoso Lago de Jubará. Francisco narra experiências advindas de um saber culturalmente internalizado e incorporado, não necessitando, por isso, de maiores explicaçóes e detalhes.

Francisco da Silva nem mesmo chamava Copéa de rio, "morava no Copéa", "ficou no Copéa"; apenas depois de eu pedir maiores explicaçóes, "Copéa é o que?", tentando entender o mapa narrado, foi que ele o nomeou como um rio. Em seguida, pensa um pouco, lembra-se do município de Porco Magro localizado no Rio Copéa e que só se fez necessário em sua narração a partir da minha necessidade de uma maior compreensão dos espaços reconstruídos nas histórias de Francisco.

Para ele, diferente do pesquisador, naquele momento quase não existia separação entre cidade e rio, entre terra e água, entre homem e meio: “e o Copéa e o meu tio”, ambos formavam um corpo único. A síntese de algo que 
lhe é natural, internalizado em sua cultura, bastava para uma compreensão estranha, ou, ao menos, não de todo inteligível para mim. ${ }^{4}$

Anísio Pedro da Silva respondeu-me secamente que tinha nascido no Rio Ituxi, o que me desconcertou de novo: onde seria isso? "É longe de Manaus, Seu Anísio?”, retruquei tentando, a partir do local que mais conheço, Manaus, aproximar-me dos caminhos de Anísio que, quase já sem paciência, respondeu: "duas faia [falhas, pequenos braços de rio] acima de Lábrea”, município no Rio Purus, braço esquerdo do Solimóes, por via fluvial a $1.672 \mathrm{~km}$ da capital.

Creuza de Andrade foi mais "intransigente" ainda: "nasci no Jaú". E eu, outra vez tentado me "achar": "é rio acima, ou rio abaixo Dona Creuza?". "Ah! Não sei se é com rio pra cima nem pra baixo, é Jaú!" Só depois de algumas pesquisas descobri tratar-se de um pequeno afluente na margem esquerda do Rio Negro, próximo ao antigo distrito de Airáo que nunca apareceu nas narraçóes de Creuza.

João Cesário da Silva não lembrou muito bem o nome do lugar em que nasceu no Manaquiri, talvez em uma das muitas "outras comunidades" do Lago Janauacá, onde Vivaldo Correa ia pescar com seu pai e onde também encontrei Maria do Nascimento, "lá pra dentro". João lembra-se, no entanto, do terreno de sua avó "lá no Manaquiri”, mais precisamente no Lago do Limão, onde passou divertidos momentos de sua infância, “...8 pra 10 anos, por aí...", recordou.

Para os meus interlocutores, são esses territórios líquidos os berços de suas origens, sua primeira identidade a qual recorrem para dar sentido às memórias e histórias de suas vidas, posicionando-se, finalmente, em uma complexa cartografia social. Mesmo tentando, para a comodidade da pesquisa, identificar, "negociar" uma cidade, vila ou distrito, comumente referendado como locais de nascimento que posicionam e identificam, para os narradores, nesse ponto, não existe acordo.

Nas narrativas de Francisco, Anísio, Creuza e João, a cidade, o distrito, a vila, o povoado confundem-se como uma paisagem secundária, quase um adendo às suas histórias e trajetórias. $\mathrm{O}$ rio, o lago, o paraná, pelo contrário,

4 Nesses termos, o professor Alessandro Portelli, em seu trabalho de campo, comenta: "Sempre estamos pedindo às pessoas para serem mais explícitas em suas referências de tempo, fazendo-as lembrar que estão falando para uma audiência que inclui, pelo menos, um estranho" (Portelli, 2004, p. 305). 
são os berços lembrados, o lugar social do acontecido, a expressão cultural em maior relevo de suas narrativas, sintonizando, por esses vieses, as ideias do historiador amazonense Samuel Benchimol, quando nos afirma:

As nossas interaçóes não podem ser ainda expressas entre o homem e a terra, mas sim entre o homem e a água, entre o homem e o rio principalmente. O caboclo não diz, por exemplo: "nasci em Humaitá", prefere dizer: "nasci no Madeira"; não diz "casei-me em Santa Isabel", mas "casei-me no Rio Negro"; não diz "vim de Benjamin Constant", mas "vim do Solimôes". O homem assim nasce, casa e vive e morre no rio. Todos nós na Amazônia somos filhos do rio (Benchimol, 1977, p. 439-440).

\section{Rio que sobe, rio que desce}

Tradicionalmente, o lugar do caboclo ribeirinho é o espaço mediano das várzeas, uma espécie de "entremundos", coexistindo entre as terras firmes onde cresce a floresta alta - ricamente extrativa e território de caça - nos "fundos" de sua janela e o rio que corre à frente de sua porta, ancoradouro e estrada para suas montarias (pequenas embarcaçôes da Amazônia), lugar de suas casas, pescas, trabalhos, festas e rituais.

Como nos advertiram as reflexóes de Thompson (1987, p. 31-32), ao contrário do sustentado por um consagrado senso comum, segundo o qual a floresta é projetada apenas como um espaço economicamente infértil, animada apenas por uma sequência interminável e homogênea de árvores, rios e terras; ela é, sem dúvida, uma complexa gama de comunidades, atividades e especializadas formas de manuseios de seus múltiplos recursos.

Nesse mundo médio, vive e trabalha o ribeirinho amazônico, ele sabe que sazonalmente (em média de seis em seis meses) suas terras baixas serão inundadas pelas águas, daí a importância estratégica das suas casas pernaltas, nas quais as palafitas amazônicas são a principal expressão da praticidade do seu tapiri, cuja construçáo, à base de palha e madeira leve, facilita seu deslocamento para as terras altas e secas.

As suas construçóes flutuantes, a começar pelas formas de algumas casas, que podem deslocar famílias inteiras pelas estradas líquidas, sazonal 
ou definitivamente, moram e/ou eventualmente mercadejam, construções de que se valem em épocas de grandes alagaçóes. Os seus jiraus e marombas também são flutuantes: os primeiros são canteiros onde os moradores plantam verduras e ervas para saciar sua fome e amenizar suas febres; já as marombas formam uma espécie de curral aonde sobem suas criaçóes para passar as enchentes, tentando salvá-las da ferocidade das águas, cobras e jacarés sempre à espreita.

Mas o ribeirinho também não esquece que as mesmas águas fertilizarão suas terras e, logo depois de emergirem, estarão prontas para os roçados, canteiros e cultivos. Ele sabe que é hora de enterrar a mandioca, plantar o bananal, a melancia; reforçar a semeadura das verduras, das ervas; limpar o quintal, ajeitar a rede de pesca, preparar o caniço; sonhar com a safra da juta, do cacau, da castanha; renovar as esperanças e rezar para que a próxima enchente chegue no tempo exato e na medida certa.

A floresta não é apenas "mato" e rio, como apregoam os desavisados e adeptos de sua esterilidade, toda uma vida de relaçóes entre homem e natureza é ali experimentada. ${ }^{5}$ Estar atento ao ciclo das cheias e vazantes com seus valores, sinais e significados pode representar a diferença entre vida e morte, sucesso e fracasso, esperança e frustração.

A aclimatação, por exemplo, de fibras vegetais náo originais da regiáo como a malva, e especialmente a juta, ambas originárias da Índia, só alcançaram resultados comerciais significativos (final da década de quarenta) quando os especialistas começaram a estudar o significado do regime das águas para os terrenos varzeanos do Careiro (Mapa I). A partir de então, as exportaçóes de juta, sobretudo para o estado de São Paulo, seguiram um ritmo de crescimento.

O padrasto de meu entrevistado, João Cesário, começou na Ilha do Manaquiri (Mapa I) uma pequena criação de gado. A criação não ia muito bem, então ele resolveu mudar de ilha, trazendo, como me contou Joáo, todo o rebanho para o Careiro, alojando-o em outro terreno da família.

Ali, o padrasto de João perderia quase todo o gado para a grande enchente de 1944, por culpa, segundo o entrevistado, de sua pouca experiência

5 Esse senso comum formou-se, também, em virtude das matas de terra firme formarem a esmagadora maioria da área florestal amazônica que, dos $3.374 .000 \mathrm{~km}^{2}$, contribuem com $3.303 .000 \mathrm{~km}^{2}$, ficando as várzeas, igapós e mangues, juntas, com $77.000 \mathrm{~km}^{2}$ (Batista, 1976, p. 112-113). 
com a pecuária: "ele num sabia das coisas, só sei que deu aquela enchente grande e o campo deles náo suportou mais o gado deles, nem o nosso".

Será que as tais "coisas" se referem tão somente à inabilidade de seu padrasto com a criação? Acredito numa "meia verdade"; possivelmente tais "coisas" signifiquem vários daqueles valores, sinais e significados do meio natural ao qual o ribeirinho deve estar atento mas, ao que sugerem as narraçóes de João, passaram despercebidos pelo seu padrasto.

Trocar o Manaquiri pelo Careiro em tempos de cheia é algo muito arriscado, sobretudo quando ela é mais volumosa do que de costume e a de 1944 foi assim. Sabidamente, as terras do Careiro recebem as águas dos rios Solimóes e Amazonas, sem contar o imenso Lago dos Reis do meio da ilha. Naquela região, as enchentes são mais ferozes e inclementes, o padrasto de João não pareceu sensível a isso também.

O volume das águas de 1944 não deu tempo para o padrasto de João Cesário tanger o gado para as terras mais altas da ilha e, muito menos, para preparar as estratégicas marombas; os currais flutuantes nunca apareceram nas narrativas de João. Quem cria gado nessas terras deve saber de uma "rota" de fuga e estar preparado para construir marombas que podem salvar várias cabeças do rebanho; o padrasto de Joáo mais uma vez esqueceu, ou desconhecia essa peculiar cultura material do lugar. Sua criação, que já não vinha muito bem, foi quase liquidada pelas águas de 44 .

No entanto, também encontrei "histórias de sucesso" e outras surpreendentes relaçóes entre moradores e o regime dos rios. No diálogo com Creuza Rodrigues de Andrade que, no Rio Jaú nasceu em 1940, morando com a família por vários beirais fluviais do interior amazônico, pude perceber outras experiências desse mundo mediano das várzeas, cujos significados e valores a família de Creuza se mostrou sensível.

Ela, primeiramente explicou-me o conceito de várzea, na sua pronúncia "vagi", a fartura do lugar propiciada pelas cheias periódicas e como as terras eram planejadas para o plantio. A riqueza do diálogo acentuou-se justamente quando não compreendi a pronúncia, resultando em sua explicação original e rica:

LS- Como era morar no interior nessa época?

CA- Ah! Era bom demais, a gente trabalhava com roça, trabalhava e plantava verdura, vigi! Ninguém comprava verdura, a maior parte do pessoal, 
verdura, porque a gente nem plantava macaxeira, quando a vagi ia saindo, sabe o que é vagi?

LS- Faço uma ideia, mas acho que eu nunca vi.

CA- Uma coisa aqui é Terra Firme, sabe o que é Terra Firme né?

LS- Sei, sei.

CA- Aí essa parte dessa casa de lá, ela enche, aí ela seca, entendeu? Ela seca de novo, aí fica, quer dizer que a gente mora em Terra Firme e lá é a vagi tá, aí a gente lá, quando as terras tão saindo a gente plantava macaxeira, plantava jerimum, tudo isso a gente plantava. (Entrevista com Creuza Rodrigues de Andrade, Manaus, Março de 2008).

Quando perguntei a Sebastiāo de Souza Garcia sobre o Manaquiri, interior onde nasceu em 1938 e viveu até os quatorze anos, notei também a presença deste "entremundos": "Manaquiri lá [onde nasci] é um... terra firme, terra firme e vargem [várzea]”. E, em seguida, surpreendi os fortes significados que o regime das águas (enchente/vazante) tem nas narrativas e na vida de Sebastião: "geralmente agora, essa época é seco lá onde a gente morava, mas também tem um tempo que é cheio o rio né, que enche, mês de... e aí uma época dessa fica seco o rio né, mas mês de... enchente é cheio também o rio né”.

Mais que recordar, Sebastiāo revive no presente, "geralmente agora", "uma época dessa", as cheias e vazantes experimentadas nas ribeiras do Manaquiri; reencena, alargando e estreitando os braços, projetando-os para frente e para trás, o alcance das enchentes. As repetiçóes, em sua fala, de palavras como cheio e seco, também são outros indicadores dessa força cultural que o sobe e desce das águas significou e significa para a sua vida.

Apenas no decorrer das conversas com Sebastião pude dimensionar melhor esses significados. Foi por conta da enchente de 1953, a maior do século passado no Amazonas, que ele deixou a Ilha do Manaquiri para tentar a sorte em Manaus, onde, definitivamente aportou aos quinze anos de idade.

A descomunal enchente transformaria de forma definitiva a sua vida. Sebastiâo não conheceu seu pai, falecido quando sua mãe estava com seis meses de gravidez, não lembra da mãe que morreu quando ele tinha um ano. Foi criado por uma tia e o marido dela que nunca conseguiram ter um filho e adotaram Sebastião de "registro" e de coração; com quatorze anos, decidiu: "vou arranjar uma mulher pra mim". Conheceu Neuza, casaram e conceberam um filho. 
Logo depois o tempo "encrespou", as chuvas caíram a ponto de parecer não acabar mais, enchendo as cabeceiras dos rios; as águas desceram velozes, solapando as margens, transformando os beirais mais expostos, arrancando plantaçóes, reconfigurando as fronteiras líquidas para se acalmar apenas sobre as terras ribeirinhas, várzea adentro.

Conforme havia combinado com o pai de criação, Sebastião iria apenas "passá a enchente" em Manaus, na casa flutuante do cunhado no bairro da Cachoeirinha, ajudando-o na venda de verduras na feira do bairro. Quando as terras principiassem a "sair" do fundo das águas, o que só começou acontecer em fins de 1953, ele pretendia retornar ao Manaquiri para ajudar o pai na roça e, sobretudo no cultivo da juta.

Sebastião contou-me que, depois de receber as boas novas do pai, até voltou, "nós vamo lá vê como é que tá as terra lâ", mas apenas para comunicar-lhe que tinha decidido, a contragosto de Neuza, ainda incomodada de morar no flutuante do irmão, permanecer em Manaus e continuar tentando a sorte como vendedor de verduras e pimentas pelos mercados e ribeiras da cidade.

Sebastiáo lembra-se com detalhes da conversa com seu pai quando replanejaram o futuro de suas vidas, completamente alterado pela decisão de Sebastião de abandonar a agricultura. O pai, agora sem a ajuda do filho, parecia ter decidido também deixar, ou ao menos não priorizar, o árduo trabalho com a juta, ficando apenas com o plantio de uma agricultura de subsistência e um pequeno cultivo de nível comercial.

Assim, ao mesmo tempo em que redividem as funçóes das terras, à luz de sua nova realidade, o pai de Sebastiáo, por intermédio das narrativas do seu filho, nos dá conta também de como essas ricas terras varzeanas eram exploradas e planejadas pelos ribeirinhos após as cheias sazonais dos rios. A conversa entre pai e filho, como sugere o trecho abaixo, foi rápida e tranquila, ambos parecendo já conscientes da irreversível mudança que as incríveis águas de 1953 haviam provocado em suas vidas:

Pai - Rapaz é o seguinte, se você mesmo não for trabalhar na parte mais baixa da terra, eu vou plantar um milho e a parte mais alta, a lombada maior, vou plantar uma roça.

Filho - Tá papai, pode plantar e eu vou voltar pra Manaus, se eu num achar que eu não tou bem, não arranjá dinheiro pra comprar lá um flutuante pra 
mim, naquele tempo era flutuante, aí eu volto, venho me embora pra cá, vou indo pro que é meu né.(Entrevista com Sebastiāo de Souza Garcia, Manaus, Novembro de 2009).

As águas de junho de 1953 foram um divisor na vida de Sebastião: "foi donde eu mi achei”. De carvoeiro, roceiro e cultivador de juta nas terras baixas arrendadas da ilha, Sebastiāo, em Manaus, vira "Sabá", feirante há mais de meio século na profissão, verdureiro conhecido no mercado público do bairro da Cachoeirinha, local em que começou a trabalhar e a morar em um flutuante sobre as águas do igarapé homônimo.

Por causa da enchente achou uma profissão, "completei 55 anos no ramo!", frase orgulhosamente repetida por ele ao longo de nossas entrevistas. Através do seu ofício adquiriu sua primeira casa, um flutuante vizinho ao cunhado, em seguida uma casa em terra e, finalmente, onde hoje mora, um terreno num dos bairros da cidade. Vendendo verduras e principalmente pimentas, criou os quatro filhos, chorou a perda de seu primogênito e, recentemente, a de Neuza. Mas, por outro lado, sorriu também com a chegada dos netos.

Inconscientemente, Sabá acredita que a enchente que o empurrou para Manaus tenha lhe "dado" uma profissáo, uma família e um nome, ou seja, uma nova identidade; por isso ele nunca se refere a ela com pesar, pelo contrário, é ela que dá sentido à maior parte de sua história, atravessando e fomentando sua narração.

Francisca Pereira da Silva, do alto de seus quase cem anos de vida, não lembrou, para minha frustração, de maiores detalhes das grandes enchentes no Amazonas, mesmo a famosa de 1953 quando ela já era adulta e mãe de quatro filhos: “... mi lembro não, seu menino!", sussurrou em tom de lamentação.

Todavia, de vez em quando, ao longo da conversa com seu filho Francisco da Silva, pude auscultar algumas histórias que Francisca subitamente começava a repetir. Para ela, tratava-se de enchentes muito vivas, com águas que "comiam a terra" e produziam monstros devoradores de gente, reencenando um imaginário mítico próprio do lugar, repleto de lendas e seres fantásticos que, por outro lado, significam as memórias e as histórias de Francisca, como no dia em que, viajando entre Coari e Tefé, contou-me: 
... Nós ia pro rio Solimóes, aí que aquela enchente grande! (risos) Uma vez, seu menino, nós tava, aquilo boiava e sumia, boiava e sumia no meio do Solimóes, meu Deus! Aí os menino: "umbora lá vê o que è", pois não era a piraíba, engoliu o homem, não aguentou, ficou a metade do homem pra fora, praticamente o homem morre aí... . (Entrevista com Francisca Pereira da Silva, Manaus, Setembro de 2008).

Em outra enchente, nem mesmo as engenhosas marombas foram capazes de salvar as galinhas e o cachorro de Francisca da Silva, devorados por uma imensa sucuriju, "tinha era muito!", lembrou ainda espantada com a ferocidade da cobra que, segundo outro entrevistado, João Cesário da Silva, na cheia de 1953 nem crianças e adultos estavam a salvo de seus ataques: "quando dava fé, a cobra tinha entrado na rede pra pegar a pessoa, é entrando pegando criança de vários lugares por aî”.

Ainda assim, os silêncios de Francisca em relação à grande cheia de 1953 intrigavam-me. É pertinente destacar a fragilidade de uma vida de quase cem anos, sendo compreensíveis as falhas e os esquecimentos de sua memória.

No entanto, em meio às narrativas de seu filho, Francisco Pereira da Silva, de relance, pude flagrar um revés em suas vidas ocorrido ao longo dos desdobramentos da incrível enchente de 1953. Depois de mais de dez anos de união, o marido de Francisca abandonou a família, talvez ele não tenha resistido às águas destruidoras da alagação, ou algum outro acontecimento de ordem pessoal o tenha motivado a deixar Francisca com cinco filhos pequenos em Coari.

Muito dos esquecimentos e lapsos de Francisca sobre a enchente de 1953 talvez se devam a esse fato marcante de sua vida e da de seu filho que, para minha surpresa, mesmo tendo apenas quatro anos de idade, lembra-se de vários detalhes da enchente. Se as águas grandes de 1953 animam-se, para ela, pelo abandono do marido, alimentando silêncios, mágoas e reticências, para seu filho, no entanto, a traumática separação tornou muito viva as recordaçóes da enchente, momento em que seu pai foi embora.

6 Piraíba é um peixe que alcança três metros de comprimento, conhecido como "peixe-fera" por se alimentar de outros peixes. Nunca se comprovou serem capazes de devorar pessoas. Coari e Tefé são cidades no Alto Solimões. 


\section{O marítimo e o fazedor de barcos}

As águas que identificam e fertilizam a terra, sendo fonte de interações diversas, são ainda para os amazônidas fontes que alimentam não apenas o corpo, mas também as mentes, na medida em que inspiram sonhos e projetos futuros.

Anísio da Silva, por exemplo, contou-me que desde menino sempre teve "vontade de trabalhar a bordo", ou seja, como marítimo; a função? Foguista, maquinista, motorista ou qualquer outra, pouco importava; para ele, o essencial era viajar, viver num mundo de aventuras que só as águas traiçoeiras, contadas, cantadas e encantadas da Amazônia poderiam lhe propiciar.

Queria dar vazão às suas fantasias, alimentadas pelas histórias ouvidas do pai, paraibano seringueiro que, antes de se estabelecer no Rio Ituxi, onde Anísio nasceu num 14 de março de 1937, foi de muitas andanças pelos ramais aquáticos mais recônditos na região.

Rio esse, à época de Anísio, ainda um porto procurado por muitos seringueiros atrás do látex, que, a duras penas, mantinha-se com algum valor comercial nas praças de Manaus e Belém. Porém, o mais importante para Anísio, a profusão de histórias, só aumentava, realimentando as fantasias do menino, aproximando-o do seu sonho e náo permitindo que ele desistisse.

Já com 25 anos, o sonho virou destino: "Por que o senhor veio para Manaus Seu Anísio?" "Porque é o destino da gente né, o destino, eu embarquei como um cachorro, um gato a bordo, não tinha documento, não tinha nada, aí eu cheguei aqui (em Manaus)". Ele, intimamente, sabia que se permanecesse na área do Rio Ituxi, voltada para as culturas extrativistas, dificilmente conseguiria "trabalhar a bordo". Por isso, quando decidiu, não mediu esforços, tomou uma lancha e veio para a capital, maior porto do estado, onde as mais diferentes embarcaçôes se encontram e de onde partem em uma movimentada vida portuária. Ali sim, as chances seriam maiores.

Em Manaus, todavia, o início foi bastante difícil, nada muito diferente do que ele estava acostumado em sua "feroz" vida de seringueiro. Tentou entrar no $27^{\circ}$ Batalhão de Caçadores do Exército, ouvindo dos militares que já estava "velho" demais para isso. No quartel ainda "descobriu" que para ter 
chance na cidade grande precisava de documentos. Voltou a Lábrea e depois de acalorada discussão com as autoridades dali, retirou o tal do "atestado de residência”, parte de uma burocracia urbana, isso sim, muito diferente do que Anísio Pedro estava acostumado em seu rio de nascimento.

Documento em mãos, já morando em Manaus, nesse momento da conversa com Anísio pensei: "agora ele vai conseguir trabalhar a bordo", porém, sonho é sonho! E eles não se realizam facilmente assim na vida real. Por motivos não muito claros para mim, ${ }^{7}$ vários anos se passariam até que Anísio se tornasse um homem do "mar".

Precisando sobreviver, Anísio passou cinco anos trabalhando na fábrica de cerveja Miranda Corrêa, "trabalhava distribuindo cerveja pela rua, em todo canto". Mas, não eram essas ruas e cantos que deveriam permanecer na mente do ex-seringueiro e sim os caminhos e recantos dos rios lá fora; de gênio forte, Anísio vivia metido em discussões com outros funcionários da fábrica, até que numa dessas, foi despedido.

Após a fábrica de cerveja, passou seis anos como foguista na Usina de Luz da cidade. Todavia, não eram as fornalhas da usina que Anísio queria alimentar, trocaria de bom grado essas fornalhas pela caldeira de um gaiola, de um vaticano, ou de qualquer outro barco.

Quase doze anos de Manaus e nada de "trabalhar a bordo". Pensei que Anísio, nesse ponto de sua vida, teria desistido ou esquecido de seu sonho de menino. Contudo, uma melhor reflexáo em suas lembranças narradas e se percebe que o rio sempre esteve em seu caminho, fazendo-o lembrar-se de seu sonho e do seu "destino".

Se a fábrica de cerveja era quase "dentro" do Igarapé de São Raimundo, a Usina de Luz era às margens do Igarapé dos Educandos. Anísio, às vezes também tomava a catraia para chegar ao serviço, contornava o Rio Negro até a embocadura com os igarapés, se fosse para a cervejaria tomava as águas do São Raimundo; para a usina, entrava nas dos Educandos. E o mais significativo, Anísio foi morar na beira do Igarapé da Glória (no bairro de mesmo nome) em um pequeno flutuante de onde podia divisar boa parte do Rio Negro, o vaivém dos barcos no Porto de Manaus e ancoradouros menores espalhados pelo litoral da cidade.

7 Talvez a inaptidão de Anísio para com os serviços a bordo. Ele, até os 25 anos, sempre fora seringueiro, chegou numa Manaus de 1962, de franca disputa por postos de serviços, sobretudo os ligados ao rio. 
Depois da Usina de Luz, ou melhor, depois das histórias que ouviu quando criança no Rio Ituxi, da seringa, de vir "como um cachorro" para Manaus, das rejeiçóes no $27^{\circ} \mathrm{BC}$, das brigas em Lábrea, de doze anos trabalhando, a fortuna lhe sorriu: "aí eu fui ser marítimo e trabalhei em muitos cantos, daqui pra Belém e para outros lugares".

Enfim, nos rios Anísio pôde viver as histórias (contos, lições, causos e lendas) que, desde menino, sempre o impressionavam, dar vazão ao seu gênio indômito, próprio da personalidade dos marítimos, sintonizado aos rompantes das águas em que navegava.

Quando acabou, uma de suas filhas o levou, já muito doente, para morar no apertado, mas de nome também simbólico, Beco da Cacimba no bairro da Glória, onde o encontrei, mas não sem ouvir os veementes protestos do velho e ainda "brabo" marinheiro que, desde então, fala aos quatro cantos, precisamente para a filha, presente na casa na hora da entrevista: "minha filha mi tirou do céu (beira do igarapé), botou pro inferno! (Beco da Cacimba)".

Anísio insistia em permanecer amarrado ao mundo das águas que inspirou seus sonhos, representou seu destino e projetou seu futuro, signos que ali nas margens do Igarapé da Glória, mesmo depois de aposentado, ele podia continuar experimentando, bem diferente do Beco da "Cacimba", seu endereço nos últimos seis, sete, dez anos. Ele náo fez a menor questáo de lembrar o tempo em que estava ali. No beco, espremido entre casas, pessoas e barulhos, Anísio Pedro não pode mais ver e ouvir o banzeiro do igarapé, as embarcaçóes indo e vindo no rio.

João Cesário da Silva, por sua vez, fazia barcos e não decidiu fazê-los tão somente por uma questão de sobrevivência. A intimidade com o ofício começou com uma de suas brincadeiras preferidas no Lago do Limão, na Ilha do Manaquiri: fazer barcos de brinquedo e colocá-los para navegar, "eu achava bonito, sempre gostei, desde menino gostei disso, fazia aqueles barquinho".

Quando deixou o Manaquiri, por volta de 1944, aos doze anos, ainda era um menino e, em Manaus, de rios e igarapés grandes e movimentados, bem diferentes do tranquilo lago de sua infância, pouco podia dar vazão à sua brincadeira infantil preferida. De qualquer forma, eram os barcos da cidade grande, sobretudo os maiores, que mais lhe chamavam atençáo.

Quando perguntei: "o que o senhor se lembra da cidade de Manaus, dos lugares que o senhor andou?”, percebi a cidade reconstruída na proporçáo 
do regime das águas que João, desde a época do interior, sempre conheceu muito bem e, especialmente, pela movimentação dos barcos:

...Esse igarapé aqui num secava (inaudível) tinha um navio do JG Araújo, o navio, quando terminava o barco da borracha, os navio ficava ali dentro, ali tinha um pontáo grande que era oficina deles, aí eles, faziam reparos nas máquina do navio, na época do rio seco, isso aí no gaiola sabe; faziam as experiências depois voltava pra lá, num secava isso aqui não. ${ }^{8}$ (Entrevista com João Cesário da Silva, Manaus, Junho de 2005).

Já "homem feito", João Cesário buscou nas experiências dos folguedos infantis do Lago do Limão a inspiração para o trabalho que abraçou por mais de meio século. A brincadeira virou "profissão de carpintaria naval" os "barquinhos" de antes viraram barcos de recreio, de passeio, rebocador de balsa, "... todo tipo de barco era eu que fazia" e fazia muito bem, pois, segundo me contou, sua fama de ótimo fazedor de barcos chegou até Belém, aumentando sua clientela.

No final da segunda entrevista, eu já havia desligado o gravador, João me trouxe três fotografias dos seus últimos trabalhos. Tratava-se do aumento no comprimento de um grande barco chamado "Comandante Paiva"; poucos acreditavam ser possível aquele serviço, mas João, já em idade avançada, o fez. Olhando para as fotos, mais do que tentar me explicar o processo, que eu pouco compreendia, João parecia querer reviver tempos antigos em sua oficina nos fundos do quintal de sua casa, às margens do Igarapé dos Educandos, onde mora desde 1955.

Suas sofridas mãos, ele perdeu um dedo para a serra elétrica, gesticulavam o tempo, costuravam histórias nos ensinando, tal como Walter Benjamim, que "... a mão intervém decisivamente, com seus gestos, apreendidos na experiência do trabalho, que sustentam de cem maneiras o fluxo do que é dito" (Benjamim, 1986, p. 221). Um desses modos, o gesticular das mãos de João Cesário, ao mesmo tempo em que tentavam reconstruir barcos, procuravam também brincar de fazer "barquinhos" no Lago do Limão de sua infância.

8 JG Araújo foi um dos poucos negociantes da borracha que conseguiram sobreviver à crise da produção a partir dos anos vinte. À época de João Cesário, JG Araújo, graças a uma diversificação em seus negócios, ainda sustentava um bom prestígio econômico na regiâo. 


\section{Fontes orais}

\section{Anísio Pedro da Silva}

Nascimento: 14 de Março de 1937

Local: Rio Ituxi, Lábrea-Amazonas

Profissão: aposentado

Relação com a "cidade flutuante": morador

Data da entrevista: 13 jan. 2008

Creuza Rodrigues de Andrade

Nascimento: 26 de Outubro de 1940

Local: Rio Jaú-Amazonas

Profissão: aposentada, vendedora de churrasco

Relação com a "cidade flutuante": moradora de 1962 a 1967

Datas das entrevistas: 15 mar e 12 set. 2008; 09 dez. 2009

\section{Francisca Pereira da Silva}

Nascimento: 20 de Setembro de 1913

Local: Coari-Amazonas

Profissão: "do lar"

Relação com a "cidade flutuante": morador de 1963 a 1966 aproximadamente

Datas das entrevistas: 15 jan. e 23 set. 2008

\section{Francisco Pereira da Silva}

Nascimento: 07 de Setembro de 1949

Local: Coari-Amazonas

Profissão: vendedor ambulante

Relação com a "cidade flutuante": morador de 1963 a 1966 aproximadamente

Datas das entrevistas: 15 jan. e 23 set. 2008

\section{Joáo Cesário da Silva}

Nascimento: 08 de setembro de 1931

Local: Manaus

Profissão: construtor naval (aposentado)

Relação com a "cidade flutuante": vizinho

Datas das entrevistas: 17 jun. 2005; 27 set. 2008; 29 nov. 2009

\section{Maria do Nascimento Borél}

Nascimento: 1918

Local: Janauacá-Amazonas

Profissão: "do lar"

Relação com a "cidade flutuante": teve suas terras ocupadas em 1968 por ex-moradores Data da entrevista: 15 jan. 2008 


\section{Sebastião de Souza Garcia}

Nascimento: 10 de Janeiro de 1938

Local: Manaquiri-Amazonas

Profissão: feirante desde 1953

Relação com a "cidade flutuante": morador de 1953 a 1958

Datas das entrevistas: 12 fev. 2006; 26 jan., 06 mar. e 18 out. 2008; 20 nov. 2009

\section{Vivaldo Correa Lima}

Nascimento: 06 de Setembro de 1935

Local: Manaquiri-Amazonas

Profissão: policial militar, cabo reformado

Relaçâo com a "cidade flutuante": morador de 1949 a 1967 aproximadamente

Datas das entrevistas: 25 jan. 2006; 06 mar. e 01 out. 2008; 21 nov. 2009

\section{Referências}

ARANTES, A. Augusto. Paisagens paulistanas: transformaçôes do espaço público. Campinas: UNICAMP, 2000.

BATISTA, Djalma. O complexo da Amazônia: análise do processo de desenvolvimento. Rio de Janeiro: Conquista, 1976.

BENCHIMOL, Samuel. Amazônia: um pouco antes, além e depois. Manaus: Umberto Calderaro, 1977.

BENJAMIN, Walter. O narrador: consideraçóes sobre a obra de Nikolai Leskov. In: Magia e técnica, arte e política - ensaios sobre a literatura e história da cultura. Coleçâo Obras Escolhidas, v. I. 2 ed. São Paulo: Brasiliense, 1986. p. 197-221.

BITTENCOURT, Agnello. Corografia do estado do Amazonas. Manaus: ACA, 1985.

PORTELLI, Alessandro. O momento da minha vida: funções do tempo na história oral. In: FENELON, Déa et al. (Org.). Muitas memórias, outras histórias. São Paulo: Olho d’Água, 2004. p. 296-313.

ROLNIK, Raquel. História urbana: história na cidade? In: FERNANDES, Ana; GOMES Marco Aurélio de F. (Org.). Cidade e história: modernização das cidades brasileiras nos séculos XIX e XX. São Paulo: EDUSP, 2001. p. 141-142.

RONDON, Federico. Pelos sertôes e fronteiras do Brasil. Rio de Janeiro: REPER, 1969.

SÉRIE AMAZONIANA. O Amazonas em Números. Publicação Oficial da Interventoria Federal (1942). Manaus, 2002. 
SOARES, Lúcio de Castro. Amazônia. Rio de Janeiro: Conselho Nacional de Geografia, 1963.

SOUZA, Leno José Barata. Cidade Flutuante: uma Manaus sobre as águas (1920-1967). Tese de Doutorado (Programa de Pós-graduação em História da PUC-SP). São Paulo-Pontificia Universidade de São Paulo, São Paulo, 2010.

THOMPSON, Edward Palmer. Senhores e caçadores: a origem da lei negra. Rio de Janeiro: Paz e Terra, 1987.

Resumo: Em meio à antiga "Região de Manaus" (e ainda nas cercanias desta), o artigo busca discutir, para além de uma mera paisagem ambiental, o valor do complexo hídrico para os amazônidas. À luz de algumas memórias dos nossos entrevistados, potencializamos as águas fluviais do lugar enquanto território das mais plurais convivências, meio de moradia e trabalho, fonte de histórias peculiares que dão a conhecer não apenas as ideias e o imaginário dos moradores da região, como são partes intrínsecas de sua identidade cultural.

Palavras-chave: Amazonas, história ambiental, história oral.

\section{The cultural importance of the waters in the Amazon}

Abstract: Amid the old "region of Manaus" (and in the vicinity thereof), the article discusses the value of the complex water for amazônidas beyond a simple landscape environment. In light of some memories of our interviewees, we encourage the river water of the place as a territory of more plural cohabitation, living and working environment, a source of peculiar stories not only make known the ideas and imagination of local residents, as an intrinsic part their cultural identity.

Keywords: Amazonas, environmental history, oralhistory.

Recebido em: 15/03/2012

Aprovado em: 27/04/2012 